を使用している，異なった機能をすつ 2 つのX線管と 2 つのプックフィルムチェンジャが， 正側両方向とむ抎大 率が 2 倍となるよう設置されており被検者体軸回りに， 土45度の回転及び頭尾方向に士30度の傾斜機能をもつ. 1 度の造影剤注入で立体拡大連続撮影・2 方向高速連続 撮影等撮影術式が豊富で，質的・量的にも情報量がおお い. 透視・撮影のX線中心を合致させているので，位置 決めや中心合わせの操作が容易で検查が簡素化できる.

27. ビデオ・グラフィーの試み（第一報）

東北大学附属病院放射線部

○梁川 功・遠藤久勝・有馬宏寧

東北大学医療技術短期大学部部療放射線技術学科

片会 䦌・大石幹雄

画像記憶装置はX線 TV 検査において，大幅な被曝低 減と CRT 動画像を静止画像として反復再生することに より，運動体の分析比較観察が容易にでき，広くX線診 断に用いられている. 我々は乙の検査中並行して行なわ れる直接撮影を省く目的で, CRT 画像から多階調高鮮 明のハードコピー（ビデオグラフィ）を得るよう基礎的 実験を試み良好な結果が得られた。つまり，スキャンコ ンバータを用い映像信号を重神書きで, 記憶させること により, 細部の描出が明瞭で充分に臨休に利用出来るこ とが解った。

28. ビデオグラフィーの試み（第 2 報）

東北大学附属病院放射線部

○有馬宏寧・遠藤久勝

梁川 功・佐藤州彦

東北大学医療技術短期大学部㟝療放射線技術学科

片倉 剛! 大石幹雄

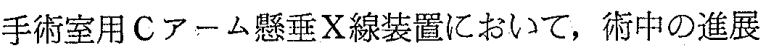
状況の比較観察, 被艆線量の低減, 作業の効率化を計る ため,ビデオグラフィーシステムの導入を試みた. シス テムの構成は，東芝メディカルと共同開発したスナップ ショットビジョンと呼ぶ画像入出力装置と、マ、ルチホー マットカメラ, 自現機を直結した転写フィルム処理装置 から成る. 概要は, TV の走查線数 875 本, 映像読み込 込は, 5 フレーム $(0.2$ 秒 $)$ を加算平均し 1 フレームとし て記録する. 又読込み時にブースト信号により $50 \% \mathrm{X}$ 線 量を増す.とれらはメモリ一画像の画質向上に寄与する. 尚，メモリ一枚数は15枚である.

現在，麻酷科神経ブロックに使用している。

29. 䨑科用 $\mathrm{X}$ 線管焦点のレスポンスについて

東北歯科大学附属病院 ○营野忠夫

購入したばかりの二台(外国製)，4年間フルに使用し
たもの三台（国産）の歯科用X線管焦点のレスポンスの 比較を行なった. 結果, 後者の方が明らかにレスポンス が良く，それに比し前者二台は半影と散乱線によるレス ポンスの低下が著明であった，良し画質に慣れてしまっ た読影側から前者のもので得られた写真に，問題がある という指摘 (再撮影) ああった. ノンスクリーンシステ ムにおいて焦点のレスポンスの低下はストレートに画質 に響く、睛入してしまってから焦点のレスポンス云々し ても始まらない，今後，製作者に品質試験の一貫として 行なった「焦点のレスポンス测定票」の添付，あるいは そのことを行政的に義務付けられるととを望む.

30. マイクロコンピュータとミクロホトメータによる

\section{R.M.S 測定法}

福島県立医科大学放射線科

○加藤和夫 ・ 山田久夫 中田隆則・上田 稔

医療用 X線写真の画質は, 鮮鋭度, 粒状性, 調子再現 の3因子によって構成されている. 現在てれらの評価方 法として, MTF, RMS 粒状性，ウィーナースペクトル， などが一般に用いられている。

近年マイクロコンピュータは著しく発達し, より高性 能，低価格となり，様々な用途に利用されるようになっ てきた．今回，手近に有る汎用マイクロコンピュータ と，そクロフォトメータを結合する事により， RMS 粒 状性測定の利用を試みた. 結果として, 現在の一般的方 法の電卓計算と比べた場合, RMS 值は良好で, 一度プ ログラムしておけば，何回も利用でき，労力も格段に軽 減するととが出来た。

\section{X 線撮影系における低コントラスト MTF 測定法 の検討}

\author{
福島県立医科大学放射線科 \\ ○青山正勝・上田 稔 \\ 山口，満・片倉俊彦
}

従来X線撮影系における MTF の測定は, 高コントラ ストを呈する被写体が用いられて来た。私共はより実際 の被写体に近い低コントラストを呈する被写体による MTF 測定を試みた。低コントラストを呈する被写体に おいてはピンホール及び矩形波からの像解析は困難であ り，エッヂ法を用いた従来の MTF 測定を比較検討し， 測定法による差がほとんどない事を確認した. 次にマン モ゙ー装置及びノンスクリーンフィルムを用い，鉛及びア ルミエッヂによる MTF を測定すると有意の差が, “得ら れた。更にエッヂにアクリル被写体を入れ MTF を測定 するとその結果から見て被写体を含む系の MTF は，高 